\title{
Brexit: An uncertain journey
}

Even our international Evidence Based Nursing journal readers will have heard about the recent referendum in Britain. On $23^{\text {rd }}$ June 2016, the 46 million Great British electorate were asked 'should Britain remain in the European Union (EU) or not?' Of the $72 \%$ of the population who voted, $17,410,742(51.9 \%)$ were of the opinion that Britain should leave the $\mathrm{EU}^{1}$. Subsequent breakdown of the results indicates that there was division according to age, social class, education qualification and geographical location ${ }^{2}$ with younger, more educated and urban citizens tending to vote remain.

After what was for some a surprising result, the main question has been what happens next? Without access to a crystal ball, the UK has entered a period of uncertainty and speculation abounds. Uncertainty is present in many aspects of the post Brexit referendum world including nursing. Brexit could have many repercussions for nursing and healthcare. Helen McKenna, Senior Policy Adviser at the King's Fund explores five health and social care aspects that might be impacted ${ }^{3}$. These are: staffing, accessing treatment here and abroad, regulation, cross-border cooperation, and financial.

UK healthcare is already under considerable economic pressure ${ }^{4}$. Healthcare spending is intrinsically linked to UK Gross Domestic Product. Following the referendum, many forecasters predict a reduction in economic growth ${ }^{4}$. Thus, according to Health Foundation modelling, National Health Service spending could be £2.8 billion less than currently budgeted ${ }^{4}$. Without increased governmental funding or taxation, current austerity healthcare measures will need to continue or increase in severity.

Staffing is clearly an important worldwide issue to nursing ${ }^{5}$. In 2014, the UK National Audit Office estimated that there was a $27,980(7.2 \%)$ shortfall in nursing, midwifery and health visiting staff ${ }^{6}$. Strategies to address this shortfall, such as using temporary staffing and recruiting from overseas, could be affected by Brexit. Using temporary staff is expensive for healthcare providers already struggling to balance their books. This is especially relevant as further "efficiencies" are required ${ }^{4}$. Recruiting from overseas could become more difficult if access to the European workforce is restricted in a post-Brexit UK. Worldwide, as some countries struggle to retain home trained staff, in the face of lucrative UK contacts, this could be viewed as a good thing 5 . Whilst back in the UK proponents of Brexit state that moving to an Australasian style points system would enable Britain to control entry and attract people with desirable qualifications. However, in Australia this approach has not enabled adequate recruitment of nurses ${ }^{7}$. In addition, British nursing shortages could be worsened if the UK becomes a less attractive place to work ${ }^{8}$. There is already some evidence that European nurses who have been working in the UK are returning to their home countries.

Close to the hearts of Evidence Based Nursing readers is the potential impact Brexit may have on research. Here there is also uncertainty. Some eminent names in British Research have opposing views on Brexit's research impact ${ }^{9}$. Professor Sir Paul Nurse's view is that Brexit could be the largest threat to UK research 'in living memory'. Whist Brexiters, such as Emeritus Professor Howard Morris, see new opportunities to negotiate our own grant deals ${ }^{10}$. However, without access to valuable research funds such as Horizon 2020, a trickledown effect could see researchers competing over a smaller pot of available funds. This could mean important research or innovation is neglected. 
Uncertainty will reduce with time. However, with no apparent political will to go against the referendum decision, UK healthcare will need to respond to the challenge of Brexit. For healthcare, and patients that we provide care for, it is important for nursing to be part of shaping this future. This involves being politically active at a local and national level. In addition, we need to ensure that our overseas staff feel valued in the work place.

\section{Follow Dr Stephen McKeever on Twitter @StephenMcK}

Senior Lecturer in Children's Nursing, Department of Children's Nursing, London South Bank University

Competing interests: UK Green Party Member, lives in London and voted remain.

\section{References}

1. The Electoral Commission. EU referendum results London 2016 [Available from: http://www.electoralcommission.org.uk/find-information-by-subject/elections-andreferendums/upcoming-elections-and-referendums/eu-referendum/electorate-andcount-information.

2. Uberoi $E$, Keen R, Hawkins O. Brexit: how did the UK vote? London: The House of Commons Library; 2016 [updated 24 June 2016. Available from: https://commonslibraryblog.com/2016/06/24/brexit-how-did-the-uk-vote/.

3. McKenna $\mathrm{H}$. Five big issues for health and social care after the Brexit vote London: The King's Fund; 2016 [Available from: http://www.kingsfund.org.uk/publications/articles/brexit-and-nhs.

4. The Health Foundation. NHS finances outside the EU London: The Health Foundation; 2016 [Available from:

http://www.health.org.uk/sites/health/files/NHSFinancesOutsideTheEU 0.pdf.

5. Buchan J, Calman L. The Global Nursing Shortage: Priority Areas for Intervention Geneva: International Council of Nurses; 2006 [Available from: http://www.icn.ch/images/stories/documents/publications/GNRI/The Global Nursing Shortage-Priority Areas for Intervention.pdf.

6. National Audit Office. Managing the supply of NHS clinical staff in England London 2016 [Available from: https://www.nao.org.uk/wp-content/uploads/2016/02/Managing-thesupply-of-NHS-clinical-staff-in-England.pdf.

7. Health Workforce Australia. Australia's Future Health Workforce - Nurses Canberra 2014 [Available from:

https://www.health.gov.au/internet/main/publishing.nsf/Content/34AA7E6FDB8C16A ACA257D9500112F25/\$File/AFHW\%20-\%20Nurses\%20detailed\%20report.pdf.

8. Merrifield N. European nurses feel chill after Brexit vote London: Nursing Times; 2016 [updated 4 July 2016. Available from:

http://www.nursingtimes.net/news/workforce/exclusive-european-nurses-feel-chillafter-brexit-vote/7006109.fullarticle.

9. Ghosh P. Paul Nurse: 'Research needs free movement to thrive' London: BBC.; 2016 [updated 29 June 2016. Available from: http://www.bbc.co.uk/news/scienceenvironment-36667987.

10. Morris HR. Open letter to the UK science community London: Scientists for Britain; 2016 [updated 11/06/2016. Available from:

http://scientistsforbritain.uk/wordpress/?p=259. 